Schleimen aus Carcinomen von Magen, Gallenblase und Ovar nur selten nachweisen. Im Mucin primärer Adenocarcinome der Lunge fehlen sie vollständig. Auf Grund dieser Befunde kann bei Neoplasmen der Lunge der histochemische Nachweis dieser Sialinsäuren herangezogen werden, um Metastasen von Coloncarcinomen von primären Lungentumoren und Metastasen anderer Organe zu unterscheiden.

Schliisselwörter: Neoplasmen der Lunge - Coloncarcinom - Kohlenhydrat-Histochemie - O-acylierte Sialinsäuren.

342. H. Becker, J. Horn, H. Gohbauer, H. Schmidt-Gayk, Heidelberg: Neue Aspekte in der Verlaufskontrolle der operativen Behandlung der akuten Pankreatitis.

Manuskript nicht eingegangen

\title{
343. Pankreasfragmenttransplantation und Pankreasgangocclusion - Ein Konzept zur Erhaltung der endokrinen Funktion bei CRP
}

\author{
H. V. Zühlke, R. Häring, U. Watermann, G. Grosse, J. Konradt, L. C. Tung und E. von Natzmer \\ Chirurgische Klinik und Poliklinik im Klinikum Steglitz der Freien Universität Berlin \\ (Geschäftsf. Dir.: Prof. Dr. R. Häring), Hindenburgdamm 30, D-1000 Berlin 45
}

\section{Transplantation of Pancreas Fragments and Occlusion of the Pancreatic Duct - A Concept for Maintenance of Endocrine Function in CRP}

Summary. Transplantation of autologous pancreas fragments in minipigs leads to normalization of the carbohydrate metabolism. If, however, fibrotic pancreas tissue is prepared, normalization cannot be achieved. Complications of the intraportal implantation are DIC, thrombosis and portal hypertension. Long-term investigations revealed no functional loss of the implanted endocrine cells. As long-term metabolic and histological investigations have shown, occlusion of the pancreatic duct leads to impairment of the endocrine function of the Langerhans' cells.

Key words: Transplantation of pancreas fragments - Pancreatic duct occlusion - Endocrinological investigations - Long-term results.

Zusammenfassung. Die Transplantation von autologen Pankreasfragmenten führt bei Zwergschweinen zu einer Normalisierung des Kohlenhydratstoffwechsels. Wird dagegen fibrosiertes Pankreasgewebe aufbereitet, kann eine Normalisierung nicht erzielt werden. Komplikationen der intraportalen Implantation sind DIC, Thrombose und portale Hypertension. Langzeituntersuchungen ergaben keinen Funktionsverlust der implantierten endokrinen Zellen. Die Pankreasgangocclusion führt, wie die Stoffwechsel- und histologischen Langzeituntersuchungen zeigen, zu einer Beeinträchtigung der endokrinen Zell-Leistung des Inselorgans.

Schliisselwörter: Autogene Pankreasfragmenttransplantation - Pankreasgangocclusion - Endokrine Untersuchungen - Langzeitergebnis.

344. E. Biemer, W. Stock, W. Duspiva, München: Neue Möglichkeiten der Gewebetransplantation.

Manuskript nicht eingegangen 